\title{
Association Between Polymorphonuclear Leukocyte Cell Percentage in Cerebrospinal Fluid and Outcome of Tuberculous Meningitis Patients in a Tertiary Hospital in Indonesia
}

\author{
Amanda Widayanti, ${ }^{1}$ Ahmad Rizal, ${ }^{2}$ Ida Parwati, ${ }^{3}$ \\ ${ }^{1}$ Faculty of Medicine Universitas Padjadjaran, Indonesia, ${ }^{2}$ Department of Neurology Faculty of Medicine \\ Universitas Padjadjaran/Dr. Hasan Sadikin General Hospital Bandung, Indonesia, ${ }^{3}$ Department of Clinical \\ Pathology Faculty of Medicine Universitas Padjadjaran/Dr. Hasan Sadikin General Hospital Bandung, Indonesia
}

\begin{abstract}
Tuberculous (TB) meningitis is the most severe type of extrapulmonary TB with high morbidity and mortality rates. Many factors affect patient outcome, including the intracranial inflammation process. In acute inflammation, recruitment of a high number of polymorphonuclear (PMN) cells can cause edema which may eventually increase the intracranial pressure. This increase in intracranial pressure may lead to functional decline, disability, and even death. This study aimed to explore the association between the PMN percentage in cerebrospinal fluid (CSF) and TB meningitis patient outcome as measured by the Glasgow Outcome Scale at Dr. Hasan Sadikin General Hospital Bandung, which is a tertiary hospital in Indonesia. This was a retrospective cohort study using patient medical record data from 2017. All TB meningitis patients over 18 years old were included. Patients with missing PMN results in medical record were excluded, which led to a total 88 subjects participating in this study. Variables analyzed were PMN percentage in CSF and patient outcome that were categorized as poor, moderate, and good. Analysis were performed using theKruskal-wallis test. An increase in PMN median as the patient outcome declined were observed, but the association between the PMN percentage in CSF and patient outcome was insignificant $(p=0.186)$. Hence, no association between PMN percentage in CSF and TB meningitis patient outcome was identified in this study.
\end{abstract}

Keywords: Cerebrospinal fluid, tuberculous meningitis, outcome, polymorphonuclear (PMN) cell

\section{Hubungan Persentase Sel Leukosit Polimorfonuklear dalam Cairan Serebrospinal dan Luaran Pasien Meningitis Tuberkulosis di Rumah Sakit Pusat Indonesia}

\begin{abstract}
Abstrak
Meningitis tuberkulosis (TB) merupakan merupakan jenis TB ekstraparu paling berat dengan morbiditas dan mortalitas tinggi. Berbagai faktor memengaruhi luaran pasien, salah satunya proses inflamasi intrakranial. Pada inflamasi akut, terjadi peningkatan sel polimorfonuklear (PMN) dan bila dalam jumlah tinggi dapat menimbulkan efek edema yang meningkatkan tekanan intrakranial. Peningkatan tekanan intrakranial ini menyebabkan penurunan fungsi otak, disabilitas, bahkan kematian. Penelitian ini bertujuan untuk mengetahui hubungan persentase PMN dalam cairan serebrospinal (CSS) dan luaran glasgow outcome scale (GOS) pada pasien meningitis TB di RSUP Dr. Hasan Sadikin Bandung. Penelitian ini merupakan studi retrospektif cohort menggunakan data rekam medik tahun 2017. Kriteria inklusi adalah pasien terdiagnosis meningitis TB dan berusia $\geq 18$ tahun. Kriteria eksklusi adalah data rekam medik yang tidak lengkap untuk hasil PMN. Variabel yang diteliti adalah persentase PMN dan luaran pasien yang dikategorikan menjadi GOS buruk, sedang, dan baik kemudian dianalisis dengan uji Kruskal-wallis. Didapatkan 88 subjek yang memenuhi syarat. Terdapat peningkatan median PMN seiring derajat perburukan luaran namun hasil analisis menunjukkan tidak terdapat hubungan yang bermakna antara PMN dan luaran GOS pasien $(\mathrm{p}=0,186)$. Simpulan, tidak terdapat hubungan antara persentase PMN dalam CSS dengan luaran GOS pasien meningitis TB.
\end{abstract}

Kata kunci: Cairan serebrospinal, luaran, meningitis tuberkulosis, sel polimorfonuklear (PMN)

Corresponding Author: Amanda Widyanti, Faculty of Medicine Universitas Padjadjaran, Jalan Raya Bandung-Sumedang KM 21 Jatinangor, Sumedang, Indonesia, Email: amandawidayanti@gmail.com 
A Widayanti et al: Association Between Polymorphonuclear Leukocyte Cell Percentage in Cerebrospinal Fluid and Outcome of Tuberculous Meningitis Patients in a Tertiary Hospital in Indonesia

\section{Introduction}

Tuberculosis is an infectious disease caused by Mycobacterium tuberculosis bacteria. ${ }^{1}$ This disease is the ninth leading cause of death worldwide and the number one leading cause of deaths due to infection of one agent. Indonesia currently has the second highest number of TB patients in the world after India with a total incidence of 391 per 100,000 population. ${ }^{1,2}$ Tuberculosis most commonly affects the lungs, which is referred to as pulmonary TB. However, it can also affect other body organs, known as extrapulmonary tuberculosis (EPTB).

TB meningitis is a manifestation of EPTB that is identified in the brain lining and is considered one of the most severe types of EPTB with high morbidity and mortality. Although it contributes only to $9.8 \%$ of all EPTB cases, $33 \%$ of TB meningitis died and $50 \%$ of those who survived became disabled. Mortality of these patientes is affected by delayed diagnosis and treatment.,4 Despite treatment, the mortality of TB patients remains high with an estimate of $25 \%$ for HIVnegative patients and $67 \%$ for HIV-positive patients with the majority of deaths occur in the first month of hospital admission. ${ }^{5}$

Several factors influence the patient outcomes, including age (>60 years), low Glasgow Coma Scale (GCS) score at admission, hydrocephalus, severity of TB meningitis (Medical Research Council stage III), hydrocephalus, presence of stroke and seizures, involvement of cranial nerve (palsies), cerebrospinal fluid (CSF) profile (cell count, lactate level), HIV coinfection, and drug resistance..$^{5-10}$ One of the commonly used outcome parameters is the Glasgow Outcome Scale (GOS), ${ }^{11}$ which is initially used to assess outcomes after brain trauma. This measurement is then used for other conditions affecting the brain, including TB meningitis.,

One interesting indicator in determining the outcome of TB meningitis patients in addition to the above factors is the inflammatory process. The inflammation occurring in the brain has a different process when compared to the inflammatory process in other parts of the body. ${ }^{12,13}$ When inflammation occurs in the brain in response to pathogens, various inflammatory effects can be triggered to protect the brain, which can eventually lead to cerebral edema. Cerebral edema can be harmful because the brain is contained in a rigid compartment of the skull thus edema can lead to increased intracranial pressure, which later can damage the brain or even lead to death. ${ }^{13}$ In other words, leukocytes, as an indicator of inflammation, are thought to affect the outcome of TB meningitis patients. ${ }^{12}$

Research on the association between inflammation in $\mathrm{TB}$ meningitis and patient outcomes as a prognostic factor has been carried out with a result that high neutrophil count in CSF lead to higher mortality. ${ }^{14}$ However, the association of between the PMN percentage as an indicator of inflammation and GOS outcome of patients in Indonesia has never been investigated. Therefore, this study aimed to analyze the association between the percentage of PMN leukocyte cells in CSF and the outcome of TB meningitis. The results of this study are expected to be used as a consideration whether the PMN percentage in CSF could be used as a predictor of outcome for TB meningitis patients.

\section{Methods}

This study was a retrospective cohort analytic study to analyze the association of PMN leukocyte cell percentage in CSF and the outcome of TB meningitis patients treated at the Department of Neurology, Dr. Hasan Sadikin General Hospital, Bandung. Data used in the study were secondary data taken from medical records of TB meningitis patients throughout the year 2017. Data collection was performed from August to September 2018.

The inclusion criteria for this study were diagnosis of TB meningitis and aged $\geq 18$ years. Patients were excluded if the leukocyte differential count of the CSF examination could not be retrieved.

The variables in this study consisted of PMN leukocyte cells percentage in CSF as the independent variable and outcome of TB meningitis patient as the dependent variable as measured by Glasgow Outcome Scale (GOS) consisted of five main categories: (1) death, (2) a persistent vegetative state with minimal response, (3) severe disability with the patient conscious, dependent on others for daily activities, (4) moderate disability where patients may be able to independently go on with daily activities in suitable conditions, and (5) a good recovery in which the patient can return to normal life with a minor deficit. The GOS results were further categorized into the three categories of GOS to avoid data gaps but still enable the distinction between patients who died and those who live with or without disabilities through the categorization of poor GOS (GOS 1); moderate GOS (GOS 2-3); and good GOS (GOS 4-5). ${ }^{11}$ 
Demographic information of each patient, as well as clinical and laboratory data, was also collected to show patients' characteristics. TB meningitis gradings were done based on the British Medical Research Council criteria i.e. grade I (GCS 15 without focal neurological deficits); grade II (GCS 11-14 with/without focal neurological deficit or GCS 15 with focal neurological deficit); and grade III (GCS less than 11 with/without focal neurological deficit). ${ }^{10}$ Variables such as sex, age, temperature, TB meningitis grading, CSF parameters, and clinical criteria were obtained from the initial assessments. Results of cerebral imaging and chest radiography were also retrieved while the GOS was calculated using the clinical data at discharge.

Data analysis was done using the IBM SPSS Statistics 22.0. Data were then analyzed descriptively to recognize the data distribution. In addition, for the analysis of the association between PMN percentage variables in numerical data and GOS outcome variables in categorical data, the Kruskal-Wallis test was used based on the reason that the data were not normally distributed.

This study was approved by the Health Ethics Committee of Universitas Padjadjaran under the ethical clearance No. 430/UN6.KEP/ EC/2018 and from the Dr. Hasan Sadikin General Hospital Research Ethics Committee with the issuance of the ethical clearance number LB.02.01/X.2.2.1/13350/2018.

\section{Results}

During the study period, there were 152 medical records of TB meningitis patients with 64 were excluded due to age $<18$ years old $(n=27)$ and incomplete data $(\mathrm{n}=37)$. Eighty-eight subjects met the study criteria (Figure) and were then analyzed.

Characteristics of the subjects are listed in Table 1 . There were more male patients (67\%) with a median age of 29 years and a median temperature of $37.4^{\circ} \mathrm{C}$ among the subjects. The majority of patients had experienced advanced grading of TB meningitis, i.e. 97.7\% had grade II and grade III TB meningitis. From the perspective of clinical criteria, more than $50 \%$ of patients had a symptom duration of longer than five days $(71.6 \%)$ and experienced a change in the level of consciousness $(63.6 \%)$.

From the results of lumbar puncture examination, a majority of CSF were clear (73.9\%), with a median total cell count in CSF of 101 cells $/ \mu \mathrm{L}$. The median PMN was $33 \%$ while the median $\mathrm{MN}$ was $67 \%$. The median protein and the median glucose were $185.5 \mathrm{mg} / \mathrm{dL}$ and $25 \mathrm{mg} / \mathrm{dL}$, respectively. Cerebral imaging was available for 80 subjects. Of these, basal meningeal enhancement was a predominant feature $(65 \%)$, followed by the appearance of hydrocephalus (51.3\%), infarction (13.8\%), and tuberculoma (6.3\%). One subject can have more than one cerebral pathology. Chest radiographs suggestive of pulmonary TB were found in 40 subjects $(45.5 \%)$.

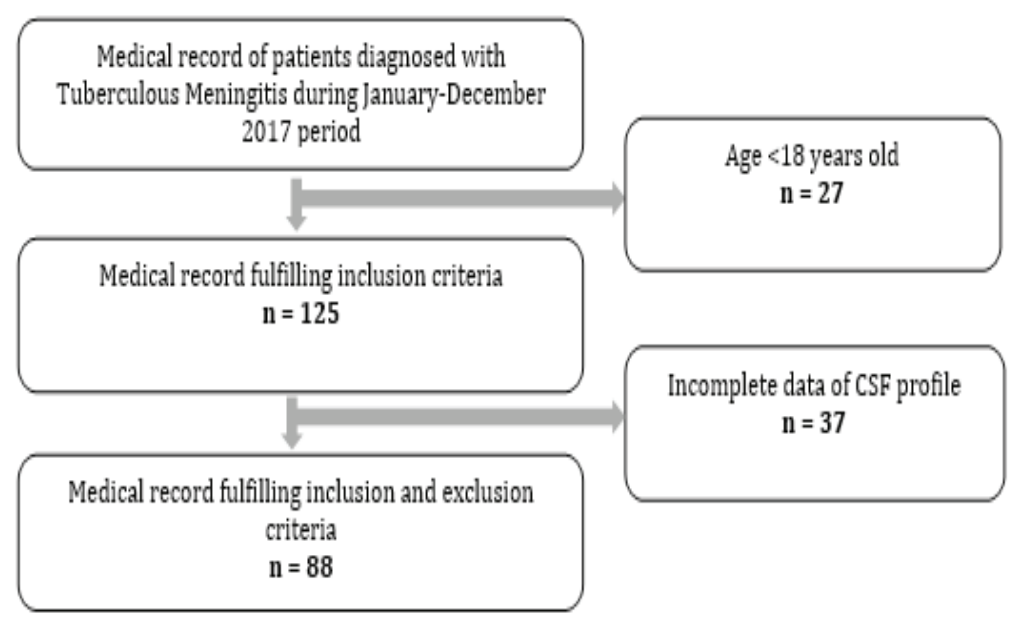

Figure Study Sample Inclusion Plot 
A Widayanti et al: Association Between Polymorphonuclear Leukocyte Cell Percentage in Cerebrospinal Fluid and Outcome of Tuberculous Meningitis Patients in a Tertiary Hospital in Indonesia

Table 1 Patients Characteristics $(n=88)$

\begin{tabular}{|c|c|c|c|}
\hline Characteristics & $\mathbf{n}$ & $(\%)$ & Median (IQR) \\
\hline \multicolumn{4}{|l|}{ Sex } \\
\hline Male & 55 & 62.5 & \\
\hline Female & 33 & 37.5 & \\
\hline Age (years) & 29 & & $18-64$ \\
\hline Body temperature $\left({ }^{\circ} \mathrm{C}\right)$ & 37.4 & & $36-39.6$ \\
\hline \multicolumn{4}{|l|}{ TB meningitis grading } \\
\hline Grade I & 2 & 2.3 & \\
\hline Grade II & 63 & 71.6 & \\
\hline Grade III & 23 & 26.1 & \\
\hline \multicolumn{4}{|l|}{ Clinical criteria } \\
\hline Duration of symptoms $>5$ days & 63 & 71.6 & \\
\hline Contact history & 31 & 35.2 & \\
\hline Focal neurological deficit & 21 & 23.9 & \\
\hline Cranial nerve palsy & 33 & 37.5 & \\
\hline Altered level of consciousness & 56 & 63.6 & \\
\hline \multicolumn{4}{|l|}{ CSF Parameter } \\
\hline Clear & 65 & 73.9 & \\
\hline Total cell count* $(\mathrm{sel} / \mu \mathrm{L})$ & 101 & & $1-2508$ \\
\hline \multicolumn{4}{|l|}{ Leukocyte percentage (\%) } \\
\hline PMN & 33 & & $0-100$ \\
\hline $\mathrm{MN}$ & 67 & & $0-100$ \\
\hline Protein concentration* (mg/dL) & 185.5 & & $33-5210$ \\
\hline CSF glucose* $(\mathrm{mg} / \mathrm{dL})$ & 25 & & $2-159$ \\
\hline \multicolumn{4}{|l|}{ Cerebral imaging } \\
\hline Hydrocephalus* & 41 & 51.3 & \\
\hline Basal meningeal enhancement & 52 & 65 & \\
\hline Tuberculoma & 5 & 6.3 & \\
\hline Infarct & 11 & 13.8 & \\
\hline \multicolumn{4}{|l|}{ Evidence of tuberculosis elsewhere } \\
\hline Chest radiography suggestive of TB & 40 & 45.5 & \\
\hline Miliary TB & 13 & 14.8 & \\
\hline AFB identification in culture* & 3 & 16.7 & \\
\hline
\end{tabular}

Note: Data is shown in total unit of n (\%) unless further explained; *Total data available was $100 \%$ for all variables, except for total cell count in CSF as much as 87 samples (98.9\%); protein concentration in CSF as much as 84 samples (95.5\%); glucose concentration in CSF as much as 86 samples (97.7\%); cerebral imaging as much as 80 samples (90.9\%); AFB as much as 18 samples (20.5\%); Abbreviations: IQR, interquartile range; TB meningitis, Tuberculous Meningitis; CSF, Cerebrospinal fluid; PMN, Polymorphonuclear; MN, Mononuclear; AFB, Acid-fast bacilli

Table 2 shows the factors known to influence the condition of TB meningitis patients from the previous studies and could be analyzed in this study. Variables that could be analyzed include sex, age, TB meningitis grading, and cerebral imaging.
The general description of PMN of the subjects and the results of the analysis using the Kruskal-Wallis test are shown in Table 3. Median PMN for the overall subjects was 33\%. There was a tendency that the poorer the outcome was, the higher the PMN percentage. However, 
A Widayanti et al: Association Between Polymorphonuclear Leukocyte Cell Percentage in Cerebrospinal Fluid and Outcome of Tuberculous Meningitis Patients in a Tertiary Hospital in Indonesia

Table 2 Association between Patient Characteristics and Patient Outcome

\begin{tabular}{|c|c|c|c|c|c|}
\hline & & \multicolumn{3}{|c|}{ Patient Outcome Category } & \multirow[b]{2}{*}{$P$ value } \\
\hline & & $\begin{array}{c}\text { Poor GOS } \\
(n=28)\end{array}$ & $\begin{array}{l}\text { Moderate GOS } \\
(n=20)\end{array}$ & $\begin{array}{c}\text { Good GOS } \\
(n=40)\end{array}$ & \\
\hline Sex & & & & & $0.906^{\#}$ \\
\hline Male & $55(62.5 \%)$ & $18(20.5 \%)$ & $13(14.6 \%)$ & $24(27.3 \%)$ & \\
\hline Female & $33(37.5 \%)$ & $10(11.4 \%)$ & $7(8.0 \%)$ & $16(18.2 \%)$ & \\
\hline $\begin{array}{l}\text { Age (years), } \\
\text { median (min-max) }\end{array}$ & $29(18-64)$ & $34(18-53)$ & $30.5(18-57)$ & $25(18-64)$ & $0.344^{*}$ \\
\hline TB meningitis grading & & & & & $0.001^{*}$ \\
\hline Grade I & $2(2.3 \%)$ & $0(0 \%)$ & $0(0 \%)$ & $2(2.3 \%)$ & \\
\hline Grade II & $63(71.6 \%)$ & $17(19.3 \%)$ & $11(12.5 \%)$ & $35(39.8 \%)$ & \\
\hline Grade III & $23(26.1 \%)$ & $11(12.5 \%)$ & $9(10.2 \%)$ & $3(3.4 \%)$ & \\
\hline Cerebral imaging & & & & & $0.206^{\#}$ \\
\hline Hydrocephalus & $41(51.3 \%)$ & $16(20 \%)$ & $12(15 \%)$ & $13(16.3 \%)$ & \\
\hline
\end{tabular}

Note: Data is shown in total unit of n (\%) unless further explained. Data was available $100 \%$ for all variables, except for cerebral imaging as much as 80 samples (90.9\%); Abbreviations: GOS: Glasgow Outcome Scale; TB meningitis, Tuberculous Meningitis; chi-square test; *Kruskal-Wallis test

the Kruskal-Wallis test showed no significant difference in PMN percentage in CSF between patients' GOS outcome categories ( $\mathrm{p}=0.186)$.

\section{Discussion}

TB meningitis is a severe extrapulmonary TB condition. Rapid treatment and prognosis determination are required, one of which can be measured from the percentage of PMN in CSF. This retrospective cohort study found no statistically significant association between the percentage of PMN in CSF and outcomes in TB meningitis patients, although there is an apparent increase in PMN as the outcome worsened. This finding differs from the results of a cohort study conducted on 608 TB meningitis patients in Indonesia, which found that mortality is associated with higher neutrophil counts in CSF (hazard ratio [HR], 1.10 per $10 \%$ increase). ${ }^{14}$ In addition, a multivariate analysis in China on 154 subjects found a higher leukocyte count in CSF as associated with worse outcomes $(\mathrm{p}=0.005)$. In contrast, a Vietnamese study found that the mortality of TB meningitis patients is associated with low leukocyte count in CSF, specifically neutrophils (including the PMN types). ${ }^{14,15}$

In view of the process of tuberculosis meningitis infection, the increase in PMN as an indicator of the inflammatory process is thought to affect the patient's outcome to become worse. As a protection against pathogens, the brain has a mechanism for inflammatory response but, if it is not controlled, it may end in tissue

Table 3 Kruskal-Wallis test for Association between PMN and TB Meningitis Patient GOS Outcome

\begin{tabular}{lccccc}
\hline & & \multicolumn{3}{c}{ Patient Outcome Category } \\
\cline { 3 - 6 } & $\begin{array}{c}\text { Median } \\
\text { (IQR) }\end{array}$ & $\begin{array}{c}\text { Poor } \\
\text { GOS (n=28) }\end{array}$ & $\begin{array}{c}\text { Moderate } \\
\text { GOS } \\
(\mathbf{n = 2 0})\end{array}$ & $\begin{array}{c}\text { Good } \\
\text { GOS } \\
(\mathbf{n = 4 0 )}\end{array}$ & P value $^{\#}$ \\
\hline PMN (\%), & 33 & 47 & 46.5 & 20 & $0.186^{*}$ \\
median (IQR) & $(0-100)$ & $(0-100)$ & $(0-100)$ & $(1-100)$ & $0.100)$ \\
\hline
\end{tabular}

Note: *Kruskal-Wallis test; Abbreviations: PMN: Polymorphonuclear (cell); IQR; interquartile range; GOS: Glasgow Outcome Scale; "Value is stated significant if $p<0,05$ 
damage. ${ }^{16}$ Inflammatory processes that occur in the brain are different when compared to those in other body organs. ${ }^{12,13}$ Anatomically, the brain and its meninges lining are covered by a rigid compartment of the skull that in conditions where the extracellular fluid volume increases, in which edema occurs due to inflammation, an increase intracranial pressure will happen, which then reduces blood flow and potentially injure the brain. Besides, the function of the central nervous system depends on minimally regenerative nerve cells. Both of these explain how the central nervous system has a limited capacity for inflammatory and immune reactions..$^{13,17}$

The accepted pathogenesis theory of TB meningitis explains that TB meningitis develops from the formation of caseous foci in the brain parenchyma or meninges around bacteria deposited in these tissues during the initial bacteremia phase. The rupture of foci allows penetration of bacilli into the subarachnoid cavity that triggers inflammatory meningitis. ${ }^{17,18}$ The immunological response that occurs when bacteria infect the central nervous system is still poorly understood. ${ }^{17}$ PMN cells, including neutrophils, are the first cells to respond when infection occurs and, as an executor of innate immunity, it functions to phagocyte bacteria. Although most TB meningitis patients generally present with CSF examinations of leukocytosis dominated by lymphocytes (MN) in the early stages of the disease, a predominant PMN response is visible within the first few hours to the first two days that is then replaced by lymphocytes as the disease develops but the number remains significant for several days to weeks. ${ }^{4,16,18}$ In an acute phase, this cellular condition can be very high, accompanied by the accumulation of extracellular fluid in the form of plasma proteins that occurs due to increased blood flow that allows immune cells to reach the site of infection, giving rise to edema and increased intracranial pressure. ${ }^{17}$ Besides, the nature of PMN itself is thought to be neurotoxic. ${ }^{19}$ PMNs secrete matrix metalloproteinases (MMPs) that play a role in tissue damage. MMP9 degrades type IV collagen, the main structure that forms the basement membrane; hence, it plays a major role in blood-brain barrier damage and tissue damage. ${ }^{19}$

Increased intracranial pressure and tissue damage can then develop into severe neurological deficits that may lead to death. Obstruction of CSF by inflammatory infiltrates leads to hydrocephalus, encephalitis is triggered when exudate comes in direct contact with the surface of the brain causing damage to underlying brain tissue, and vasculitis contributes to infarction, which has the potential to cause irreparable neurological damage. Therefore, this inhibition of inflammation might help prevent worsening outcomes in the form of neurological deficits and death. ${ }^{17}$

Other factors that were most significant to be used as outcome predictors based on previous research are HIV coinfection and TB meningitis severity. Besides, it is also known that age, low GCS score at admission, presence of hydrocephalus, seizures, cranial nerve involvement (palsies), cerebrospinal fluid profile (cell count, lactate level), and drug resistance can be used as predictors. ${ }^{5-10}$

When advanced grades of TB meningitis (grade III) are associated with worse outcomes in previous studies and in this study, a significant association is found $(p=0.001) .9,10$ older age ( $>60$ years) is also known to be associated with worse outcomes, but in this study, no significant association is found $(p=0.906) .{ }^{9,10}$ Previous studies regarding older age and worse outcomes conducted in Taiwan using a retrospective method for 108 patients and another study with the same method for 43 patients found a significant association. ${ }^{9,10}$ The presence of hydrocephalus is known as a predictor for worse outcomes based on prospective studies in India and Taiwan, but in this study a significant association was not found $(\mathrm{p}=0.206){ }^{9,20}$

It is known that in previous studies, men are more at risk for TB meningitis so that the prevalence of TB meningitis is higher in men, and the results in this study support the finding (male subjects $62.5 \%$ ), but there is no significant association with outcomes $(\mathrm{p}=0.906){ }^{3}$

The strengths of this study are the cohort research design that allows the analysis of the direction of causality and assessment of several exposure variables. There are several limitations to this study. Due to its retrospective nature, some required data are not available. Also, the data obtained cannot to represent the population well due to the distribution of study subjects that is not even between GOS outcome categories (poor GOS: 28 subjects; moderate GOS: 20 subjects; good GOS: 40 subjects). In addition, there are some cases where the lumbar puncture was not performed due to several reasons, and outcomes in TB meningitis patients are affected by various factors and not all of them are measured in this study such as HIV coinfection, GCS scores, and drug resistance that could have influenced the 
A Widayanti et al: Association Between Polymorphonuclear Leukocyte Cell Percentage in Cerebrospinal Fluid and Outcome of Tuberculous Meningitis Patients in a Tertiary Hospital in Indonesia

results obtained.

There is a tendency that the poorer the outcome is, the higher the PMN percentage but the association is not statistically significant. This may be due to the number and distribution of samples that do not adequately represent the population. The PMN percentage in CSF cannot yet be used as a parameter to determine poor patient GOS outcomes. Further studies are required, with a prospective study design to ensure a lumbar puncture examination to obtain percentage of PMN, which further examines other factors that may influence outcomes in TB meningitis patients.

\section{References}

1. World Health Organization. Global tuberculosis report 2017. Geneva. 2017;

2. Koppel BS. Bacterial, fungal, \& parasitic infections of the nervous system. In: Barbara S. Koppel, and Todd Hayano M, editors. Current diagnosis and treatment neurology. second edition. New York, NY: McGraw-Hill Education; 2011. p. 401-8.

3. Bartzatt R. Tuberculosis infections of the central nervous system. Cent Nerv Syst Agents Med Chem. 2011;11(4):321-7.

4. Van TT, Farrar J. Tuberculous meningitis. J Epidemiol Community Health. 2014;68(3): 195-6.

5. Brancusi F, Farrar J, Heemskerk D. Tuberculous meningitis in adults: a review of a decade of developments focusing on prognostic factors for outcome. Future Microbiol. 2012;7(9):1101-6.

6. George E, Iype $\mathrm{T}$, Cherian $\mathrm{A}$, Chandy $\mathrm{S}$, Kumar A, Balakrishnan A, et al. Predictors of mortality in patients with meningeal tuberculosis. Neurol India. 2012;60(1):1822.

7. Li K, Tang H, Yang Y, Li Q, Zhou Y, Ren M, et al. Clinical features, long-term clinical outcomes, and prognostic factors of tuberculous meningitis in West China: a multivariate analysis of 154 adults. Expert Rev Anti Infect Ther. 2017;15(6):629-35.

8. Kee CP, Periyasamy P, Law ZK, Ibrahim NM, WanYahya WNN, Mahadzir H, et al. Features and Prognostic factors of tuberculous meningitis in a Tertiary Hospital in Malaysia. J Infect Dis Epidemiol. 2017;3:028.

9. Hsu PC, Yang CC, Ye JJ, Huang PY, Chiang
PC LM. Prognostic factors of tuberculous meningitis in adults: a 6-year retrospective study at a tertiary hospital in northern Taiwan. J Microbiol Immunol Infect. 2010; 43(2):111-8.

10. Chou $\mathrm{CH}$, Lin GM, Ku CH CF. Comparison of the APACHE II, GCS and MRC scores in predicting outcomes in patients with tuberculous meningitis. Int J Tuberc Lung Dis. 2010;14(1):86-92.

11. Jeffrey S. Kreutzer JS, DeLuca J, Caplan B, editors. Encyclopedia of Clinical neuropsychology; New York: Springer; 2011.

12. Fung A, Vizcaychipi M, Lloyd D, Wan Y, Ma D. Central nervous system inflammation in disease related conditions: mechanistic prospects. Brain Res. 2012;1446:144-55.

13. Dutta K, Ghosh S, Basu A. Infections and inflammation in the brain and spinal cord: A Dangerous Liaison. In: Jana N, Basu A, Tandon $P$, editors. Inflammation: the common link in brain pathologies. Singapore: Springer; 2016.

14. van Laarhoven A, Dian S, Ruesen C, Hayati E, Damen MSMA, Annisa J, et al. Clinical parameters, routine inflammatory markers, and LTA4H genotype as predictors of mortality among 608 patients with tuberculous meningitis in Indonesia. J Infect Dis. 2017;215(7):1029-39.

15. Christodoulides M. Meningitis: cellular and molecular basis. US: CAB Int; 2013.

16. Lowe DM, Redford PS, Wilkinson RJ, O'Garra A MA. Neutrophils in tuberculosis: friend or foe?. Trends Immunol. 2012;33(1):14-25.

17. Leonard JM. Central nervous system tuberculosis. Microbiol Spectr. 2017;5(2):10.1128/microbiolspec.TNMI70044-2017.

18. Rodrigues MG, da Rocha AJ, Masruha MR, Minett TS. Neurotuberculosis: an overview. Cent Nerv Syst Agents Med Chem. 2011; 11(4):246-60.

19. Ong CWM, Pabisiak PJ, Brilha S, Singh P, Roncaroli F, Elkington PT, et al. Complex regulation of neutrophil-derived MMP9 secretion in central nervous system tuberculosis. J Neuroinflammation. 2017; 14(1):31.

20. Modi M, Sharma K, Prabhakar S, Goyal MK, Takkar A, Sharma N, et al. Clinical and radiological predictors of outcome in tubercular meningitis: A prospective study of 209 patients. Clin Neurol Neurosurg. 2017;161:29-34. 